\title{
Závěrečný veřejný seminář Rekonstrukce politického procesu 50. let
}

Dne 2. března 2019 se na Vrchním soudě na Pankráci odehrála veřejná část Vědeckého semináře Rekonstrukce politického procesu 50. let. Již jedenáctým rokem studenti pod odborným vedením prof. JUDr. Jana Kuklíka, DrSc., děkana Právnické fakulty, prostudovali konkrétní proces, který se odehrál v padesátých letech a který byl veden s odpůrci (at' již domnělými či skutečnými) tehdejšího režimu. Jako v předchozích letech, došlo i tentokrát ve spolupráci s Mgr. Janem Řeřichou, režisérem a ředitelem festivalu Mene Tekel, jehož cílem je především připomínat důsledky totalitních režimů 20. století, k divadelnímu zpracování studovaného př́ípadu.

Letošní případ reprezentoval procesy se soukromými zemědělci, jejichž cílem bylo především demonstrovat moc komunistického režimu na venkově a prosadit socializaci venkova. Proces, který byl vybrán ve spolupráci s PhDr. Alenou Šimánkovou z Národního archivu, se odehrál v roce 1953 na Olešnicku (okres Blansko). Vzhledem k tomu, že mezi tamními zemědělci převládalo konzervativní smýšlení a úcta k tradičnímu způsobu hospodaření na půdě zděděné po předcích, odpor ke kolektivizaci a změnám byl logický. Došlo to dokonce tak daleko, že menší sedláci pomáhali těm větším, kteří měli předepsány př́liš vysoké povinné dodávky. Ty velmi dobře fungovaly jako účinný nástroj perzekuce soukromých zemědělců v jiných okresech.

Kde nestačily povinné dodávky a jiné podobné „měkčí“ donucovací nástroje, přikročila zpravidla komunistická moc k tvrdším prostředkům v podobě trestního postihu nejzarytějších odpůrců. Nejinak tomu bylo i na Olešnicku. Po zvážení informací, které o procesu máme k dispozici, je možné domnívat se, že k inscenaci celého procesu využila StB bývalého trestance Josefa Matouše. Ten v kraji vystupoval jako „západní agent Karel“, obcházel vesnice a snažil se místní získat pro údajné protikomunistické akce. Na základě toho pak byli ti zemědělci, kteří přišli s Matoušem do kontaktu, obviněni a následně odsouzeni ve dvou vykonstruovaných procesech. Výsledkem obou procesů byly dva rozsudky smrti, jeden trest odnětí svobody na doživotí a mnohaleté tresty odnětí svobody. Předmětem rekonstrukce v rámci vědeckého semináře prof. JUDr. Jana Kuklíka, DrSc. byl ten, jehož hlavní líčení se odehrálo ve dnech 17.-19. dubna 1953 v Olešnické sokolovně.

Již samotný název vědeckého semináře - rekonstrukce politického procesu - evokuje pečlivou snahu všech zúčastněných o maximální pochopení zkoumaného tématu. Tomu výrazně napomáhá práce s originárními prameny uloženými v Národním archivu. Inspirativním zdrojem byla též práce místního autora Josefa Novotného „Olešnické memento“, 
která obsahovala zajímavá svědectví př́imých účastníků olešnických procesů, a také diplomová práce historičky Marie Bočkové.

Metoda rekonstrukce procesu zúčastněným studentům přiblížila fungování mechanismu politických procesů. Seznámili se nejen s procesními instituty a formální podobou procesu, ale rovněž i s ideologickým pozadím celé události. Zvláště zajímavé byly z tohoto pohledu například př́pravné materiály, ze kterých vyplývalo, že o trestech bylo rozhodnuto ještě před započetím hlavního líčení. Nebo různá následná hodnocení procesu, mezi kterými nechyběla ani taková, která otevřeně hovořila o naprosto nedostatečném prokázání viny obžalovaných.

V neposlední řadě představuje rekonstrukce prostřednictvím divadelního ztvárnění možnost nahlédnout do charakterů zúčastněných osob, zamyslet se nad jejich pohnutkami, nad jejich jednáním a jejich motivy.

Podobně jako v minulých letech se i v rámci letošního vědeckého semináře sešli studenti, kteří neváhali participovat nejen v rámci výuky, ale také nad její rámec, ve svém volném čase. Mnozí z nich se na tomto projektu podílejí dokonce opakovaně. Jistě nebudeme daleko od pravdy, když prohlásíme, že ze studentů, kteří divadelní rekonstrukcí úspěšně završili svou práci během semestru, se stal jakýsi tým.

Zároveň je důležité připomenout, že bychom měli stále usilovat, aby právo představovalo ono příslovečné ars boni et aequi, umění dobrého a spravedlivého. A aby mohli absolventi Právnické fakulty s tímto vědomím opouštět svou alma mater, je nutné studium práva orientovat nejen na řemeslnou právnickou dovednost. Na závěr proto citujeme v tomto ohledu osobu nejpovolanější, garanta vědeckého semináře prof. JUDr. Jana Kuklíka, DrSc.: „Studium práva nemá sledovat jen získání znalostí a dovedností právnické profese, ale musí mít i svůj etický a morální rozměr. Troufám si říci, že k tomu přispívají právě takové aktivity, jako je naše dnešní setkání v porotní síni Vrchního soudu v Praze.“

doi: 10.14712/2464689X.2019.21

Lukáš Blažek

Tereza Blažková 